\title{
PARRESÍA CÍNICA E ALTERIDADE NA PERSPECTIVA DE MICHEL FOUCAULT
}

\author{
Cesar Candiotto \\ Pontifícia Universidade Católica do Paraná
}

\begin{abstract}
Resumo: $O$ artigo enfatiza o modo pelo qual Michel Foucault, em seu curso Le courage de la vérité, eleva a parresía cínica ao estatuto de uma genuína experiência filosófica de alteridade. A hipótese do estudo é que essa referência à alteridade possibilita repensar a relação entre cuidado de si e parresía: de um lado o cuidado de si deixa de se reportar a uma interioridade a ser preservada ou descoberta; e, de outro, a vida combativa da parresía cínica jamais pode ser situada como uma proposta alternativa de ocupação do poder no interior do jogo da governamentalidade política. A alteridade cínica, deduzida da verdadeiravida como vida-outra, envolve um incessante combate, tanto em relação à tentação fácil de refugiar-se na tranquilidade da cidadela interior quanto diante do temerário conformismo ao modo como a política é conduzida.
\end{abstract}

Palavras-chave: Ética, política, coragem, parresía, aleturgia, verdade

\begin{abstract}
This article emphasizes the manner by which Michel Foucault, in his course Le courage de la verité, rises the parrhesia to the status of a genuine philosophical experience of alterity. The hypothesis of this survey is that the reference to the alterity makes possible to rethink the relation between the care of oneself and parrhesia. Thus, from one hand, the care of oneself does not refer any more to an interiority that must be preserved or disclosed, from the other hand, the parrhesia cynical combative life can never be presented as an alternative proposal of occupying power in the interior of the political governmental play. Therefore, the cynical alterity, deduced from the true-life as other-life, involves an interesting battle in relation to the easy temptation of a refuge in the tranquility of the interior citadel, as well as vis-à-vis the risky conformity to the way politics is ruled.
\end{abstract}

Keywords: Ethics, politics, courage, parrhesia, aleturgy, truth. 


\section{Contextualização}

Em seu último curso de 1984 no Collège de France, Le courage de la vérité, Foucault apresenta duas perspectivas de análise da verdade. Há uma análise epistemológica da verdade quando se estuda "as estruturas inerentes aos diferentes discursos que são apresentados e recebidos como conhecimentos verdadeiros a partir de um sujeito constituinte"; mas também é possível identificar formas aletúrgicas da verdade quando se trata de "analisar, nas suas condições e nas suas formas, o tipo de ato pelo qual o sujeito, ao dizer a verdade, se manifesta, e por isso se representa a si mesmo e é reconhecido pelos outros ao dizer a verdade" (FOUCAULT, 2009, p. 4).

Desde o curso de 1980, Le gouvernement des vivants (editado em 2012), Foucault tem apresentado esta dupla perspectiva e claramente se situado na segunda delas ${ }^{1}$ ao investigar a produção da verdade nas práticas de si do mundo antigo, sendo a principal delas a prática da direção de consciência na qual o sujeito se põe a dizer a verdade a respeito de si mesmo. Trata-se de formas de autoenunciação a Outrem que produzem uma verdade concernente àquele que enuncia. Na cultura helenística e grecorromana, a produção da verdade demanda a figura do Outro para que o discípulo se constitua como sujeito no interior de um regime discursivo. Portanto, pelo menos nessa forma mais geral, a direção de consciência não teria sido uma invenção do cristianismo.

A diferença fundamental entre direção cristã e direção pagã (entenda-se, do estoicismo romano) é que, na primeira, trata-se de uma verdade que emerge do dirigido cuja autoenunciação demanda uma interpretação de quem a escuta. Essa autoenunciação tem como objeto as cogitationes, ou seja, os fluxos de pensamento verbalizados pelo discípulo. Do dirigido somente é exigida a coerência entre o que diz e os pensamentos que tem, ou os atos pecaminosos que realizou, no caso da confissão. A produção da verdade tem como índice a verbalização do fluxo dos pensamentos acompanhada de suas manifestações visíveis, como a vergonha, a enrubescência e a obediência a quem se discorre ou confessa. O estatuto do Outro no cristianismo, posteriormente identificável na cultura moderna nas figuras do médico, psiquiatra, psicólogo ou psicanalista, é bem institucionalizado.

Já na cultura pagã da antiguidade tardia, o estatuto do outro era excessivamente fluido e se referia a diferentes personagens. Como diz Foucault: ele "pode ser o filósofo profissional, mas pode ser também qualquer um." (FOUCAULT, 2009, p. 7). Em razão disso, era exigida uma qualificação mínima desse outro, diferente da qualificação institucional do diretor de

1 Ver, por exemplo, o estudo sobre Édipo, do dia 30 de janeiro (FOUCAULT, 2012, p. 71-73). 
consciência cristão que tinha um poder espiritual específico, ou da qualificação referendada pela posse de um determinado saber psicológico, psiquiátrico ou psicanalítico.

A qualificação exigida desse personagem, pouco definido na cultura antiga, está muito associada à parresía ${ }^{2}$. Designada como a fala franca (francparler), Foucault eleva esse conceito a um estatuto privilegiado de forma aletúrgica. Sem se identificar com um ato performativo, a parresía pode estar relacionada ao exercício de uma função, como a de governar; mas também, pode ser uma qualificação indissociável de um estilo de vida, como a do movimento cínico antigo. Em certo sentido, os dois últimos cursos de Foucault estão inteiramente enfocados nessas duas formas aletúrgicas de dizer-averdade $^{3}$ : em 1983, pelo viés da parresía política; em 1984, pela clivagem da parresía filosófica.

Dizer-a-verdade na parresía política está relacionada à função do governo. Exemplar no curso Le gouvernement de soi et des autres (1983, editado em 2008) é a prática do conselho filosófico ao governante, como nas análises sobre as Cartas de Platão (principalmente a Carta VII) na qual o filósofo grego narra sua experiência na corte de Dionísio, de Siracusa. Nesse caso, a parresía política se realiza quando a prática de dizer-a-verdade tem como contrapartida a escuta do monarca. O objeto da aleturgia política da verdade é a formação da psykhé do governante e, na maior parte desse curso, Foucault mostra como Platão deixa de lado a preocupação com a cidade ideal para se debruçar na tarefa psicagógica que consiste na prática do conselho filosófico a fim de levar o governante a exercer o poder de acordo com a racionalidade da cidade.

À diferença da parresía política, o ato de dizer-a-verdade na parresía filosófica excede o objetivo do exercício de uma função concreta. Na maior parte do curso Le courage de la vérité, a exigência de dizer-a-verdade está relacionada a um estilo de viver corajoso indispensável para a constituição do ethos de qualquer um, ao longo da existência. Esse novo alcance da parresía estudado por Foucault deriva de um desdobramento filosófico da tradição socrática segundo o qual a indissociabilidade entre dizer-a-verdade e a maneira de viver é indispensável para o reconhecimento de um mestre da verdade. Da referência a essa tradição é que deriva o movimento cínico, testemunhado por

\footnotetext{
${ }^{2}$ Como o conceito já tem sido objeto de diversos estudos, no Brasil e no exterior, permito assinalá-la sem itálico. Para um estudo detalhado da Parresía, cf. Revista de Filosofia Aurora (2011, n. 32).

${ }^{3}$ A parresía aparece pela primeira vez em L'herméneutique du sujet, na aula de 27 de janeiro de 1982, primeira hora, no contexto da relação entre filosofia e retórica. Cf. FOUCAULT, 2001, p. 132.
} 
Epicteto, Diógenes Laércio, Dion Crisóstomo e Luciano (Cf. FOUCAULT, 2009, p. 153ss).

Foucault trata do cinismo de modo mais detalhado em três diferentes momentos: no curso Le gouvernement de soi et des autres (aula do dia 23 de fevereiro, $1^{\text {a }}$. hora) quando compara esse movimento ao platonismo a fim de estabelecer a relação entre a filosofia e a política entre os antigos (Cf. FOUCAULT, 2008, p. 263-267); em seguida, na terceira das quatro conferências ministradas em inglês no outono de 1983, na Universidade de Berkeley, editada como Discourse and Truth. The Problematization of Parrhesia (1985) $)^{4}$; e, de modo mais sistemático, em cinco aulas do curso Le courage de la vérité, do dia 29 de fevereiro ao dia 28 de março de 1984 (FOUCAULT, 2009, p. 145-312).

Nesse ensaio interessa-nos examinar o modo como Foucault eleva o movimento cínico ao patamar de uma genuína experiência de alteridade filosófica, especialmente no curso Le courage de la vérité. O acento no cinismo como o outro da filosofia e, especificamente, da vida cínica como verdadeiravida e vida-outra são considerados o ápice da aleturgia da verdade no mundo antigo. E é nesse aspecto que o curso de 1984 não deixa de ser um testamento foucaultiano: trata-se da tentativa de projetar sua própria trajetória filosófica e sua vida política militante em direção de uma alteridade, irredutível à herança filosófica da metafísica da alma e inassimilável aos critérios normativos do discurso científico e dos padrões de normalização das práticas institucionais modernas. Entretanto, essa alteridade não deve ser entendida como uma categoria ontológica, mas como um dispositivo histórico de alteração dos valores do mundo em que se vive. Tampouco expressões conexas como "vidaoutra" designam uma exterioridade em relação às modalidades de vida vigentes, e sim uma elevação dessas modalidades ao seu limite, ao seu extravazamento.

\section{A dramatização da verdade e a vida cínica}

No início de sua exposição da parresía cínica Foucault apresenta algumas de suas características que vão de encontro ao seu modo de

\footnotetext{
${ }^{4}$ Na primeira conferência, Foucault trata do significado e evolução da palavra parresía. Na segunda, ele retoma a parresía nas tragédias de Eurípides, que já havia sido analisada no curso Le gouvernement de soi et des autres poucos meses antes; na terceira e quarta conferências, antecipa tanto o tema da parresía e a crise das instituições democráticas quanto a relação entre parresía e cuidado de si, mais tarde minuciosamente estudados no curso Le courage de la vérité. Em relação a essas conferências, gostaria de destacar a tradução italiana, de Remo Bodei, o qual elabora uma excelente introdução intitulada Dire la verità (BODEI, 1997, p. VII-XIX). Também indico a introdução à tradução em espanhol feita por Ángel Gabilondo e Fernando Fuentes Megías (Cf. Introducción, 2004, p. 11-33).
} 
problematização da aleturgia da verdade. Para começar, sublinha que do movimento cínico pouco se conhece de seu corpo doutrinário e muito se sabe sobre sua maneira de viver, sobre suas práticas de vida. Embora os textos apresentem Diógenes ou Antístenes como seus fundadores, no século I a. C, indiretamente essa fundação remonta à própria tradição socrática, como apresentada por Platão, no final do século V a. C.. Uma leitura mais genérica e leviana do cinismo poderia situá-lo, acrescenta Foucault no mesmo ano em Berkeley, como uma "forma negativa de individualismo agressivo que se desenvolveu como consequência do colapso das estruturas políticas do mundo antigo." (FOUCAULT, 1985, p. 46). A escolha de Foucault está ainda relacionada ao número significativo de adeptos do cinismo e ao escândalo de seu estilo de vida. O imperador Juliano (imperador romano nascido em Constantinopla em 331-363 e que reinou entre 361-363) chegou a retratá-los como um perigo para a cultura grecorromana semelhante à ameaça que representou o cristianismo primitivo. Foucault, seja lembrado, sempre problematizou como objeto do pensamento aquilo que se torna um perigo para uma cultura determinada, por ela posteriormente conjurada e, paradoxalmente, sua própria condição de possibilidade. Assim foi a problematização da loucura, da criminalidade e, nesse último caso, da vida escandalosa.

$\mathrm{Na}$ perspectiva do movimento cínico assim como, de resto, em boa parte da tradição socrática, o modo pelo qual uma pessoa vive constitui a marca de seu vínculo com a verdade. Os cínicos afirmavam que as verdades deveriam ser proclamadas a fim de que fossem acessíveis a todos. Por isso preferiam pregar em lugares públicos para que seus ensinamentos se traduzissem na visibilidade de sua vida pública, quase sempre provocativa e escandalosa. A atitude cínica - e essa é a razão principal do interesse de Foucault pelos cínicos - pode ser caracterizada como a encarnação radical da relação entre bios e logos, entre a prática de vida e o discurso verdadeiro.

Como salientado por Foucault, a associação grega entre discurso e modo de vida não é a mesma quando são estudados os estóicos, os aristotélicos, os platônicos e até mesmo os epicuristas, se estas correntes forem comparadas ao movimento cínico. Entre as primeiras, a referência fundamental é sempre a doutrina, as sentenças e máximas ou os princípios de suas respectivas filosofias. Já na tradição cínica, as referências são as vidas exemplares ou a figura do herói filosófico, personificada principalmente por Diógenes, o Cínico. Três marcas da atitude cínica, destacadas por Foucault, merecem nossa atenção: a pregação crítica, o diálogo provocativo e o comportamento escandaloso. Pregação e diálogo têm a ver com a tomada da palavra, com a enunciação pública do logos. Já o 
comportamento escandaloso remete ao bíos, a uma maneira de viver singular em relação à coletividade e às instituições e seus padrões de normatividade e normalidade.

A primeira marca do movimento cínico, portanto, é a pregação crítica. Essa expressão indica que os cínicos expunham seu estilo de vida não para uma audiência seleta formada por eruditos, mas para grupos que se juntavam em razão de outros interesses, como assistir uma peça de teatro, participar de uma festa, de um evento religioso ou de uma competição esportiva. Pregavam a respeito da liberdade e da renúncia à luxúria e, nesse aspecto, os cínicos abriram caminho para a própria crítica social observável, mais tarde, no cristianismo. Por certo, os primeiros cristãos absorvem esta crítica e estilo de pregação, mas, ao contrário dos cínicos, em seguida a incrementam por uma consistente doutrina propositiva. Os cínicos pregavam que as principais condições para a felicidade humana, télos último do agir humano, são a liberdade (eleutheria) e a autossuficiência (autarkeia) a partir das quais aquilo que um indivíduo precisa ter ou decide fazer dependem unicamente dele. Por isso, eles preferiram um estilo de vida completamente natural a fim de excluir as dependências comuns introduzidas pela cultura, pela sociedade, pela civilização e pela opinião. Os alvos de suas pregações eram o convencionalismo das instituições políticas, a arbitrariedades das proibições jurídicas e a artificialidade dos costumes.

A segunda marca enfatizada por Foucault nos cínicos é seu diálogo provocativo e cortante. Dessa vez, são comparados o diálogo de estilo socrático e o diálogo cínico. Ao contrário do diálogo socrático no qual é o discípulo que elabora perguntas ao mestre de filosofia, no episódio que envolve Diógenes e o rei macedônio Alexandre, retratado por Dion Crisóstomo, quem pergunta e se humilha é sempre o mais poderoso; o parresiasta cínico é quem responde, ridiculariza e desafia. Além disso, enquanto Sócrates joga com a ignorância de seu interlocutor, Diógenes quer ferir o orgulho do soberano, levando-o a reconhecer que ele não é quem imagina ser. Nos diálogos socráticos, o orgulho de alguém é ferido quando ele é levado a reconhecer que não sabe o que pensa saber; mas esse orgulho ferido é somente a consequência colateral da ironia socrática, cujo propósito principal consiste em mostrar ao indivíduo que ele é ignorante a respeito de sua própria ignorância. No caso de Diógenes, trata-se de dizer a verdade para ferir o orgulho do mais poderoso, sendo que o efeito colateral é o jogo da ignorância/conhecimento. O cínico é o verdadeiro rei sobre a terra porque somente ele pode ter realmente um estilo de vida autônomo e livre.

A terceira e principal marca do movimento cínico, identificada por Foucault, é o comportamento escandaloso. Um dos efeitos da verdade cínica é o escândalo, o choque social que a conduta esdrúxula provoca diante das 
evidências monótonas. A parresía cínica é privilegiada no curso de 1984 porque dela é constitutivo o comportamento que coloca em questão hábitos coletivos, padrões elitistas de decência, regras institucionais e a artificialidade da soberania política. Nesse sentido, esse comportamento pode novamente ser figurado pelo encontro entre o Imperador Alexandre e o filósofo Diógenes, na primeira hora da aula de 21 de março (Cf. FOUCAULT, 2009, p. 253ss). A inversão das regras institucionais começa pelo lugar do encontro: ele não ocorre na privacidade da corte de Alexandre, mas em um lugar aberto, na rua, onde vive Diógenes; segue-se ainda a alteração dos gestos: em vez de o Imperador permanecer sentado e Diógenes ficar em pé diante dele, o rei é que permanece em pé, ao passo que Diógenes está sentado detrás de um barril. Há, além disso, uma reversão na interpretação da função da realeza: Diógenes ordena Alexandre para que saia de sua frente a fim de que ele possa tomar sol. A aparente passagem anedótica não subtrai a importância do gesto, posto que a partir dele é posta em questão a genealogia mítica segundo a qual o rei, como descendente de um deus, é a personificação do sol. O cínico, pelo contrário, somente aceita a relação natural com o sol e o direito de dele usufruir e, com isso, ignora a personificação do Imperador. Os membros do movimento cínico ainda tinham um estilo de vida rude e pobre e eram desconsiderados pelos filósofos, sobretudo por Aristóteles. Para além de todas as nuances do comportamento escandaloso, Foucault está interessado no modo como o cínico faz de sua vida e de seu corpo um teatro da verdade, uma aleturgia da verdade. A exposição arriscada e precária da existência é que torna a vida verdadeira, e não aquilo que nela está escondido; por sua vez, a exposição da verdade é o que a torna inaceitável e escandalosa, desinibida e provocante.

Desse modo, pela pregação crítica, pelo diálogo provocativo e pela vida escandalosa o jogo cínico alcança os limites da transgressão. Essa aleturgia, caracterizada por uma conduta-limite demanda um modo de subjetivação da verdade irredutível a outras correntes filosóficas da cultura antiga. A esse modo de subjetivação Foucault nomeia de coragem da verdade.

\section{A singularidade da coragem da verdade cínica}

Se quisermos sublinhar a coragem da verdade cínica como um modo de subjetivação que extravasa outras correntes de pensamento do mundo antigo, urge primeiramente apontar a relação ímpar que o cinismo mantinha com a filosofia. Essa relação, como enfatiza Foucault, é paradoxal, pois se de um lado o cinismo é considerado por alguns filósofos como um movimento importante (Sêneca, Luciano, Plutarco, Juliano), por outro, ele também constitui o inaceitável da filosofia, seu espelho cortado. Exemplo 
disso é a diferença estabelecida por Foucault entre o ecletismo filosófico e o ecletismo cínico. O ecletismo filosófico denota uma forma de escolha que une, entre si, aquilo que há de comum e melhor entre as diferentes filosofias de uma época para poder ser aceito por todas e delas fazer o princípio organizador de um consenso intelectual e moral. Por sua vez, o ecletismo cínico recolhe alguns dos fundamentos das diferentes filosofias para transformá-los em uma prática que provoca repulsa e, nesse sentido, ele toma distância do consenso filosófico, ao lhe opor a estranheza, a hostilidade e o distanciamento. Portanto, o ecletismo cínico reúne os elementos mais comuns das diferentes filosofias para indicar um ponto de desprezo e de ruptura em relação à própria filosofia. Daí a relação de familiaridade e estranheza com o discurso filosófico.

Um dos elementos fundamentais dessa familiaridade e estranheza entre o movimento cínico e a filosofia antiga é o modo como a parresía é problematizada, no sentido de coragem da verdade. Para demonstrar sua especificidade no curso de 1984 é necessário examinar o curso de 1983, Le gouvernement de soi et des autres. Na conotação política da parresía antiga analisada nesse curso, a coragem é exteriorizada pela ousadia do democrata diante da assembléia ao dizer uma verdade contra uma maioria, ou, ainda, ao modo do conselho político do filósofo cortesão dirigido ao príncipe, o qual, ao escutar a verdade, poderia dele se vingar. Eis dois modos de coragem da verdade: no primeiro caso temos o personagem Sócrates quando, na Apologia, é retratado por Platão praticando um ato corajoso ao se defender contra a opinião da maioria, porém sem jamais situar-se no exterior da democracia ateniense e da Constituição da cidade ${ }^{5}$; no segundo, temos Platão na corte de Siracusa, quando ele arrisca a vida diante de Dionísio o Jovem, mas sem que sua enunciação possa ser pensada para além da instituição monárquica ${ }^{6}$. Foucault retoma estas duas modalidades de exercício da coragem política na aula do dia 14 de março de 1984, e lhes aponta um aspecto em comum. Ambas operam como uma espécie de bravura política do dizer-verdadeiro que aglutina tanto a coragem do cidadão na democracia quanto a do conselheiro político na monarquia. Trata-se de discursos arriscados, porém sem que as delimitações da Constituição da cidade ou a estrutura do governo monárquico sejam em si mesmas questionadas.

\footnotetext{
${ }^{5}$ Sobre a coragem de verdade de Sócrates em relação às instituições políticas no texto da Apologia, ver a análise da Primeira hora da aula de 15 de fevereiro de 1984 (cf. FOUCAULT, 2009, p. 67-74). Para a leitura paralela com o texto objeto de análise, ver PLATON (1997).

${ }^{6}$ Foucault trata de Platão na Corte de Siracusa nas aulas dos dias 9, 16, 23 de fevereiro de 1983. Sobre as cartas, VII e VIII, Cf. PLATON, 1997, p. 133-250).
} 
Há ainda uma subjetivação da coragem muito conhecida no pensamento antigo, que é a ironia socrática. Neste caso, a enunciação do parresiasta não está orientada diretamente à esfera da política para nela identificar um erro ou uma falsa opinião. Trata-se da coragem de dizer aos cidadãos que aquilo que eles julgam saber, na verdade, ignoram; e, em contrapartida, busca-se engendrar um novo saber que eles ignoram que sabem. Essa modalidade de dizer-a-verdade, que despertou a raiva, a vingança e até um processo contra Sócrates, tem como objetivo levar, cada um, a descobrir uma verdade que os deverá conduzir ao cuidado de si mesmos. (Cf. FOUCAULT, 2009, p. 215). Nesse caso, a parresía está orientada para uma teleologia ética.

Ainda que a bravura política e a ironia socrática sejam altamente relevantes, elas constituem formas de coragem pouco exaltadas no curso de 1984. A atenção de Foucault está dirigida à coragem cínica e seu ecletismo paradoxal. Se o democrata e o conselheiro arriscam a vida ao dizer a verdade, para dizer a verdade e porque dizem a verdade, os cínicos a arriscam porque vivem na verdade ao mostrar e expor completamente suas vidas. "Arrisca-se a vida, mostrando-a; e é por mostrá-la que se arrisca." (FOUCAULT, 2009, p. 216) O cínico enfrenta a cólera dos demais não somente pelo conteúdo daquilo que enuncia, mas sobremaneira pela forma como o vive. Somente o cínico é capaz de subjetivar a coragem da verdade radicalmente, à medida que ela remete a um estilo de existência marginal situado na periferia das formas de viver convencionais e, no entanto, totalmente visível a elas. Aqui mereceria um paralelo com outras figuras infames estudadas por Foucault, das quais se valeu a cultura ocidental moderna para se autodefinir na sua racionalidade e moralidade. Foucault mostrou, por exemplo, que a história da loucura (mas, também a história do nascimento da alma criminosa) era "a história do Outro - daquilo que, para uma cultura é ao mesmo tempo interior e estrangeiro, portanto a ser excluído (para conjurar seu perigo interior), mas aprisionando-o (para reduzir sua alteridade)". Desse modo é que os loucos foram tornados invisíveis e inaudíveis e, ao mesmo tempo, objetos de infindáveis enunciados razoáveis. Em contrapartida, o discurso e a vida cínica no mundo antigo são totalmente audíveis e visíveis e, nesse sentido, o estranhamento que eles provocam questiona os valores da cultura ao seu extremo posto que seu perigo interno não fora ainda conjurado e sua alteridade, reduzida. Além disso, a coragem cínica é a forma mais radical de aleturgia da verdade porque o discurso deixa de ser concebido como o índice principal da parresía (ao modo da ironia, do conselho, da argumentação). O Bíos é o novo índice privilegiado da produção da verdade 
ao qual o logos faz referência e encontra sua legitimidade. Não se trata simplesmente do risco assumido pela palavra na condição de democrata, como conselheiro, como filósofo, mas da própria vida continuamente exposta na crueza de sua existência. Em consequência, o parresiasta deixa de ser identificado principalmente pelo discurso verdadeiro, ao mesmo tempo em que se torna fundamental saber o que é a verdadeira vida que faz dele um parresiasta. Trata-se, pois, de saber o que há de específico na vida filosófica cínica que pode torná-la o novo índice de qualquer logos provocativo e crítico.

\section{Vida filosófica e Verdadeira vida}

Primeiramente Foucault comparou o cinismo e a filosofia antiga a partir do nível do discurso. Em ambos identificou uma relação paradoxal de familiaridade e exterioridade. De familiaridade porquanto o cinismo era uma espécie de ecletismo; de exterioridade, porque se o ecletismo buscava nas filosofias pontos de consenso, o cínico, por seu turno, reunia o que há de mais repulsivo em cada uma delas.

Mas esta não é a única e nem a mais importante novidade do cinismo antigo apresentada por Foucault. $\mathrm{O}$ que há de mais original e, ao mesmo tempo, mais relevante para seu diagnóstico da modernidade é a comparação do movimento cínico à filosofia antiga ao nível da vida, especificamente da vida filosófica. Igualmente neste caso, Foucault salienta que a vida filosófica é enfatizada entre diferentes correntes de pensamento no mundo antigo; mas que, somente o cinismo a radicalizou ao torná-la indissociável da verdadeira-vida.

Como sugeriu Pierre Hadot, em seu livro O que é a filosofia antiga?, na Antiguidade e em parte do pensamento moderno a filosofia tem sido considerada indissociável de um modo de vida. ${ }^{7}$ No entanto, não faz parte da démarche de P. Hadot o estabelecimento da relação entre vida filosófica e verdadeira-vida. Foucault concorda com Hadot que, para além do mundo antigo, também na Modernidade, em pensadores e contextos específicos, a filosofia é indissociável de um modo de vida. Do século XVI até o século XVIII, de Montaigne até a Aufklärung, passando por Espinosa, admite-se, quase sem dificuldades, que a filosofia, ao contrário da ciência, não é

\footnotetext{
${ }^{7}$ Além dos antigos, a relação entre filosofia e modo de vida é estendida aos pensadores cristãos medievais e aos renascentistas. Entre os modernos, Hadot estuda principalmente Montaigne, Descartes e Kant; e, na época contemporânea, o exemplo maior é o Tractatus lógico-philosophicus, de Wittgenstein (HADOT, 1999, p. 383-384).
} 
somente um discurso, mas também uma modalidade de vida. ${ }^{8}$ No entanto, se a "vida filosófica" tem sido uma prática recorrente da filosofia, não ocorre o mesmo quando ela é associada à "verdadeira-vida". Se de um lado for verossímil que o discurso filosófico quase sempre tem sido indissociável de um modo de vida, de outro, é praticamente indiscutível que ele negligenciou a questão da verdadeira-vida. ${ }^{9}$ Em parte, porque essa questão foi transferida desde o século IV d.C. e, no decorrer da Idade Média, para o domínio da religião; e em seguida, porque durante a Modernidade e na época contemporânea a problemática da verdade tem sido absorvida e institucionalizada pela ciência normativa. Tão logo o acesso à verdade constituiu o privilégio quase exclusivo do discurso científico, o problema da verdadeira-vida, como suporte necessário para o dizer-verdadeiro, tornou-se uma exigência inútil. Depois de séculos de confisco da verdadeira-vida pela normalização da instituição religiosa, seguiu-se sua preterição pela normatização da comunidade científica. Eis uma das razões pela qual Foucault procura exaltá-la no cinismo antigo.

A outra razão está associada às demarcações e modificações da investigação de Foucault na primeira metade dos anos oitenta, conhecida como "genealogia da ética"10. Entendida como um processo de subjetivação pelo qual o sujeito toma a si mesmo como objeto de elaboração, esta ética é designada como uma estética da existência. Foram desenvolvidas longas

\footnotetext{
8 No curso L'herméneutique du sujet Foucault já havia identificado em Montaigne a tentativa emblemática de associação entre o cuidado de si e uma estética da existência (Cf. FOUCAULT, 2001, p. 240). Por sua vez, o livro Reforma do Entendimento, de Espinosa, também havia sido mencionado, como o esforço mais notável, no século XVII, de associar "uma filosofia do conhecimento e uma espiritualidade da transformação do ser do sujeito por ele mesmo" (FOUCAULT, 2001, p. 29).

${ }^{9} \mathrm{Na}$ aula do dia 9 de março de 1983, no quadro de estudo da parresía política, Foucault afirma que "a vida filosófica é uma manifestação da verdade", um testemunho por seu próprio tipo de existência (FOUCAULT, 2008, p. 315). Em 1984, em sua Reforma do Entendimento, Espinosa "coloca bem a questão da vida filosófica e da verdadeira vida no princípio mesmo do projeto de filosofar." (FOUCAULT, 2009 , p. 217). Leibniz, por sua vez, teria sido o primeiro dos filósofos modernos quando parece ter excluído a vida filosófica da atividade filosófica. Portanto, se a questão do Ser foi aquilo que a modernidade esqueceu e, a partir disso, surgiu a metafísica (referência a Heidegger), assim também a questão da verdadeira vida foi aquilo que ela negligenciou e, com isso, ela se tornou cada vez mais indexada ao discurso científico.

10 Na verdade, depois da publicação, em 1994, dos Dits et écrits, e da edição de todos os cursos do assim chamado "último Foucault", em 2014, tornou-se completamente anacrônico designar seus últimos trabalhos a partir da bandeira da "ética". Está em questão principalmente a relação entre "o governo de si e dos outros" no qual a genealogia da ética está incluída, porém ressituada a partir de uma revisitação da política. E, por ser a governamentalidade o campo próprio e singular do último Foucault, seu início deverá ser situado a partir de 1978, quando, pela primeira vez a governamentalidade inclui, além do governo do outro, o governo de si mesmo. Sobre as novas possibilidades de leitura do último Foucault, cf. LORENZINI, D.; REVEL, A.; SFORZINI (2013, p. 8-28)
} 
análises sobre a filosofia como estética da existência na cultura grecorromana, guiada pelo princípio do cuidado de si e pela mediação da ascese. O curso L'herméneutique du sujet (de 1982) pelo viés amplo das técnicas de si, os volumes II e III de sua Histoire de la sexualité (de 1984) e o curso Subjectivité et vérité (de 1981) pela perspectiva da modulação da conduta sexual problematizaram, a seu modo, a articulação entre enunciação e maneira de viver ${ }^{11}$. Já no curso Le courage de la vérité, a vida filosófica é apresentada como uma modalidade específica de estética da existência, no sentido de objeto de contínua, porém inacabada, elaboração. Com efeito, a prática da filosofia cínica, marcada pela impermeabilidade da vida e a irredutibilidade do corpo aos processos totalizantes e individualizantes de sua captura e identificação, eleva a estética da existência ao seu paroxismo ao fazer da vida escandalosa a exteriorização da verdadeira-vida.

Entre os antigos, a vida filosófica é compreendida a partir de alguns princípios: ela é uma preparação para a vida que envolve cuidar de si mesmo; esse cuidado é mediado pela prática da ascese mediante a qual se procura estabelecer a conformidade entre a vida e os preceitos que são enunciados, entre o bios e o logos. Igualmente, o cinismo tem presente que a preparação para a vida é indissociável da preocupação do indivíduo consigo mesmo; e, ainda, esse movimento adere a princípios fundamentais como o de que somente deve ser investigado aquilo que é útil para a vida, ou de que é necessário viver conforme os preceitos que são enunciados. Entretanto, Foucault considera que este movimento introduz algo completamente diferente das demais filosofias ao postular que a verdadeira vida está assentada no princípio prático, mas não menos complexo, de que é preciso "alterar o valor da moeda" (parakharattein to nomisma) (FOUCAULT, 2009, p. 221). Pensamos que são os desdobramentos desse

\footnotetext{
11 Em um sentido mais amplo, também no curso Le gouvernement de soi et des autres, a mediação da ascese tem a ver com a tentativa de coerência entre o logos (o discurso pronunciado no recinto do exercício da política: na assembléia ou na corte) e as erga (obras, ações propriamente políticas). Por sua vez, em L'usage des plaisirs (1984), a apropriação filosófica do cuidado de si não está direcionada especificamente para uma estilística da existência, mas para objetivos polimorfos como a correção das insuficiências da preparação para a política, da transmissão da pedagogia, da constituição de uma erótica. A inexistência de uma articulação específica entre logos e bios na cultura clássica grega dos séculos $V$ e IV a.C., bem como a particularidade dessa articulação na cultura grecorromana dos séculos I e II d.C., fazem parte da estratégia arqueológica de enfatizar diferenças epocais para a construção de conceitos filosóficos (Cf. JAFFRO, 2003, p. 78). Foucault quer destacar que se do ponto de vista da história da filosofia, o período áureo do mundo antigo são os séculos de Sócrates, Platão e Aristóteles, da perspectiva da cultura do cuidado de si e da estilística da existência essa idade de ouro são os séculos de Sêneca, Marco Aurélio, Epicteto.
} 
princípio, tanto no cinismo quanto em movimentos e correntes ulteriores do pensamento ocidental, que demarcam a diferença entre esse curso derradeiro de Foucault e os demais cursos e livros dos anos oitenta.

Não será objeto de nossa análise as diversas interpretações que a história da filosofia tem atribuído a essa expressão, o que poderá ser encontrado na primeira hora da aula de 14 de março de 1984 (FOUCAULT, 2009 , p. 221-228). Basta mostrar nesse momento que, do ponto de vista etimológico (e até anedótico), essa prescrição tem um sentido negativo e pejorativo, de alteração desonesta do verdadeiro valor da moeda; mas, a partir de outra leitura, ela apresenta um sentido propositivo de alteração da efígie da moeda para restituí-la ao seu verdadeiro valor. Foucault assevera que o termo nómisma, que designa moeda, está associado ao nómos, que pode significar lei ou costume. Alterar a efígie da moeda, em seu sentido propositivo e ao modo cínico, envolve alterar os costumes sociais e convenções institucionais a partir do comportamento escandaloso. Um dos textos estudados é o discurso de Juliano, Contra os cínicos ignorantes, qual ele cogita que se o "conhece-te a ti mesmo" é um princípio dirigido a todos, já a prescrição "altere o valor da moeda" é endereçada somente a Diógenes pelo oráculo de Delfos (pelo menos, essa é uma das interpretações possíveis). Além disso, Foucault não hesita em sublinhar que essa prescrição cínica e seus desdobramentos na filosofia de Nietzsche (quando trata da transvaloração dos valores) constituem a mais antiga tentativa de radicalização da oposição entre natureza e cultura. É como se o cuidado com a alma e com a verdade, que passa pelo conhecimento de si, seja algo ao alcance de todos, de tal modo que poderá impregnar uma "cultura". Em contrapartida, a alteração das regras e costumes não é uma prescrição de vida dirigida a todos; essa modulação da coragem não é para todo mundo ou qualquer um. Ela designa uma ética da transgressão vivida por figuras menores da história da filosofia, ou simplesmente aquelas vidas infames, de pouca glória, cuja existência se assemelha ao que há de mais elementar no mundo. Entretanto, essa visibilidade do elementar da existência estampada na gesta cínica é apresentada como condição fundamental para que uma cultura possa perceber seus próprios limites e, com isso, livrar-se do excesso de suas artificialidades. Os cínicos - especialmente Diógenes rompem com os modos tradicionais de existência e com isso, tomados genericamente em relação aos demais homens, eles instauram uma vida radicalmente outra. Nesse sentido, o cinismo demarca um estilo de vida que coloca em questão quaisquer outras maneiras de viver na cultura ocidental.

Mas Foucault não se limita a comparar o estilo de vida cínico a outras maneiras de viver, quaisquer que sejam elas. Em seu último curso, 
tanto quando fala de Sócrates quanto mais adiante, quando trata dos cínicos, há uma insistência em situar sua análise - bem como a si próprio - em relação à filosofia. Por essa razão é que ele indica que a prescrição da alteração do valor da moeda se refere também e especificamente à vida dos filósofos. E nesse sentido, o modo como os cínicos encarnam esta prescrição introduz uma vida paradoxalmente outra. A proposta de uma vida paradoxalmente outra em relação ao que se alcunhava como vida filosófica tem a ver com o desenvolvimento do corpus socrático, se este último for pensado pelo fio condutor do cuidado de si (epimeleia heautou). $\mathrm{O}$ desdobramento mais corrente desse corpus é o platonismo, segundo o qual a verdadeira-vida se encontra em outro mundo. Faz parte da filosofia inaugurada por Platão a premissa de que é necessário primeiro contemplar a alma para, em seguida, se ter acesso às verdades inteligíveis do outro mundo. Curiosamente, o suporte teórico de Foucault para figurar essa premissa é o Primeiro Alcibíades, designado como o ponto de partida da metafísica da alma que se espraia na filosofia medieval e se alonga em boa parte da filosofia moderna (Cf. aula de 29 de fevereiro de 1984, $1^{\mathrm{a}}$. hora). Em 1984, Foucault situa no Primeiro Alcibíades a emergência filosófica do cuidado de si, de tal modo que o pronome reflexivo "si" designa a "alma" como objeto privilegiado. Ressalvadas todas as suas nuances e diferenças nos diálogos de Platão, este objeto encontra em A República um estatuto elevado e, definitivamente, se desdobra na "Grande" filosofia ocidental. ${ }^{12}$

Evidentemente que para Foucault os cínicos não são herdeiros dessa tradição do corpus socrático. Pelo contrário, eles constituem o exemplo

\footnotetext{
12 Veja-se a análise do Primeiro Alcibíades no curso L'herméneutique du sujet. Quando, nesse ano de 1982, Foucault propõe a teleologia do cuidado de si na Grécia do século IV a.C., este princípio é instigado em vista da aquisição da arte de governar a cidade, a qual, por sua vez, era indissociável de uma pedagogia e de uma erótica. $O$ exemplo de Foucault é o jovem Alcibíades, do diálogo homônimo de Platão. $\mathrm{E}$, nesse contexto, que envolve a relação entre o cuidado da alma e a pretensão do justo governo, o conceito de alma é contrastado com A República. No Primeiro Alcibíades, para definir o que é o governo justo, interroga-se a alma individual como modelo para a cidade. A psyché designa o eu objeto de cuidado, protótipo para o justo governo dos outros. Foucault considera que nesse diálogo de juventude Platão está distante da concepção de alma prisioneira do corpo, encontrada mais tarde no Fédon, no Fedro ou na República. Que no Primeiro Alcibíades o sujeito seja sua alma significa postulá-lo pragmaticamente como "sujeito de ação" (FOUCAULT, 2001, p. 55) que se serve dos órgãos corporais como instrumentos. Em uma ampla acepção, servir-se (khrêstai) do eu (heautoû) designa a posição singular ocupada pela alma-sujeito (diferente da atribuição metafísica de alma-substância) em relação com o mundo, com os outros e consigo. Ocupar-se de si significa ser "sujeito de ações, de comportamentos, de relações, de atitudes" (FOUCAULT, 2001, p. 56-57). A delimitação que, em 1984, Foucault atribui ao Primeiro Alcibíades, como a origem de uma metafísica da alma, em 1982 ele a refere à República. Nossa hipótese é que essa diferença de posição no curso de 1984 se justifica porque, nesse ano Foucault estabelece o contraste entre esses diálogos não mais a partir do conceito de alma, como no curso de 1982, mas pelo conceito de vida.
} 
excelso de uma filosofia "menor" cuja emergência é igualmente identificável nesse corpus. No curso de 1983, Le gouvernement de soi et des autres, ele já colocara Platão contra si mesmo ao exaltar a importância das Cartas (V, VII e VIII) diante dos grandes diálogos, como A República e As Leis. Em 1984, Foucault repete a estratégia, ao enaltecer o até então discreto diálogo Laques como a origem de um legado filosófico bem diferente daquele do Primeiro Alcibíades. No Laques, ele considera que uma das perguntas centrais levantada por Sócrates consiste em saber o que se entende por vida, quando se afirma que ela é merecedora de cuidado. Desde logo, é sublinhado o jogo entre lógos, verdade e bíos no âmbito da formação pessoal, no sentido de que a sintonia entre esses elementos torna-se fundamental na condução da própria vida. Sócrates é considerado o personagem excelso da indissociabilidade entre o discurso e a maneira de viver, condição fundamental para ser reconhecido como aquele que diz a verdade.

Foucault sublinha que quando a filosofia ocidental realça o cuidado da vida, ela propõe um estilo de vida-outra na imanência do mundo com o escopo de constituí-lo como um mundo-outro. Nessa esteira aberta por Sócrates é que pode ser situada a importância maior do movimento cínico, quando ele procura interrogar o que é a verdadeira-vida como vida-outra.

Esses dois desdobramentos do corpus socrático, considerados por Foucault como os fundadores da prática filosófica ocidental, não são totalmente estranhos entre si. Ele cogita que o platonismo, de algum modo, também situou a problemática da vida verdadeira na forma da existência outra. Entretanto, não detalha que autores ou, precisamente, quais escritos ou passagens de Platão poderiam estar inscritos nessa perspectiva. Igualmente, sublinha que o cinismo possui uma carga de "especulações filosóficas" bem estranhas à sua tradição rudimentar e tosca, mas não explica que especulações seriam estas. Foucault aponta uma perpétua "interferência" na "divergência" entre platonismo e cinismo, somente identificáveis se essas duas linhagens da filosofia ocidental forem pensadas a partir da perspectiva da "verdadeira vida"13. Ao negligenciar essa perspectiva, a história da filosofia obstaculizou a possibilidade de que o platonismo

\footnotetext{
${ }^{13}$ A parresía cristã é um dos maiores exemplos dessa mútua interferência. Foucault ressalta, evocando o cristianismo, que o gnosticismo pensou de modo sistemático a relação entre o outro mundo (perspectiva platônica) e a vida outra (vertente cínica). Relação essa que o protestantismo, principalmente com Lutero, teria renunciado, quando "o acesso ao outro Mundo poderá ser definido por uma forma de vida absolutamente conforme à própria existência neste mundo. Levar a mesma vida para chegar ao outro mundo, é essa a fórmula do protestantismo. E é a partir desse momento que 0 cristianismo se tornou moderno." (FOUCAULT, 2009, p. 228).
} 
também pudesse ter sido lido a partir de uma vida outra, assim como dificultou que o cinismo pudesse ser pensado para além de uma vida tosca.

\section{Os limites da verdade na vida cínica}

Foucault desdobra a relação paradoxal entre vida outra e outra vida a partir da ressignificação do conceito de aletheia no pensamento antigo ${ }^{14}$. A Aletheia será primeiro ressignificada como vida não dissimulada. $\mathrm{Na}$ tradição filosófica, observável no Fedro e no Banquete, a verdadeira vida não esconde nada de si mesma porque não comete qualquer ação vergonhosa que possa suscitar a repreensão dos outros. Já nos escritos de Sêneca, para levar uma verdadeira vida é preciso fazer de conta que estamos sempre sob o olhar dos demais. Epicteto, por sua vez, identifica a não dissimulação na vida que se desenrola sob o olhar da divindade que habita no ser humano; a não dissimulação é consequência da estrutura ontológica do ser humano ao modo de um fragmento do divino. Em relação a essas posições filosóficas, o cinismo repensa a não dissimulação ao modo de uma transvaloração. Trata-se da dramatização do princípio da não dissimulação na própria vida. Vida que já não se encontra sob o olhar hipotético dos outros ou do divino, mas sob o olhar efetivo dos demais no cotidiano da existência. Vida fisicamente pública, sem domicílio, que traja pouca roupa, come e dorme na porta dos templos, totalmente exposta. Vida irredutível às demais, já que vê no mal a consequência das convenções sociais e culturais. Pela vida totalmente exposta é que surge aquilo que no ser humano é da ordem natural. Esta vida não aceita as regras do poder tradicional, à medida que é considerada dependente somente da naturalidade do ser humano, como transgressão nua de todas as convenções.

No sentido antigo de vida sem mistura e independente, a aletheia é também ressignificada pelo cinismo. No platonismo, a vida sem mistura se refere à pureza da alma. Nos epicuristas, é a independência e a autarquia. Sêneca afirma ser a verdadeira vida a atitude de desprendimento virtual em relação às riquezas. Diante da possibilidade de que algum dia alguém se torne pobre, por exemplo, ele em nada mudaria sua percepção da vida. Já entre os cínicos a pobreza é real, ativa e infinita; real, porque é um despojamento material das vestes, do domicílio e da alimentação; ativa, porque não se contenta em renunciar à fortuna para permanecer na mediocridade, mas busca obter a coragem suficiente e a resistência

14 Esse estudo é desenvolvido na aula do dia 7 de março de 1984, segunda hora. (Cf. FOUCAULT, 2009, p. 200ss). 
necessária por meio de uma conduta efetiva de pobreza; infinita, porque é sempre uma pobreza inquieta e insatisfeita de si mesma.

A Aletheia é ainda ressignificada como vida reta. Na filosofia, a vida reta é a que se conduz conforme a razão, as regras e as convenções sociais. A retidão da vida cínica, por seu turno, somente está em conformidade com o domínio da lei natural. Os cínicos recusam o casamento, os tabus e as convenções alimentares. Se na filosofia antiga a animalidade é o ponto de diferenciação absoluto em relação ao homem como ser racional, entre os cínicos ela é um valor positivo. A animalidade é o modelo do comportamento material direcionado somente em função das necessidades exigidas pela natureza. Assumir o escândalo que pode proporcionar alimentar-se em público e satisfazer em praça pública as necessidades sexuais, são algumas formas de conduzir uma vida reta e real, indexada à natureza. A verdadeiravida como vida reta consiste em ressaltar a animalidade do ser humano como desafio, praticá-la como exercício e apresentá-la aos demais na forma do escândalo.

Enfim, a Aletheia está associada à vida soberana. Em Platão, filósofo é alguém capaz de estabelecer com sua alma um tipo de hierarquia que tem a mesma ordem, forma e estrutura do poder exercido em uma monarquia. Entre os estóicos, o filósofo é mais do que um rei na medida em que ele é capaz, na qualidade de conselheiro, de gerir e guiar a alma de um rei e, portanto, de dirigir a cidade. Quanto aos cínicos, sua visão de soberania não tem como referência o ideal do filósofo-rei; tampouco ela é o jogo de superioridade do filósofo em relação ao rei. A vida cínica é a personificação da soberania, porém às avessas. Normalmente, para que alguém seja rei ele precisa de uma hereditariedade e, alem disso, de uma educação. Já um cínico, como Diógenes, é rei por natureza e não precisa de educação (Paidéia), na medida em que ele se considera o descendente direto de Zeus. Se, ainda, um rei normalmente deve triunfar sobre os inimigos e depender de um exército poderoso, o que marca a realeza de Diógenes é sua vitória sobre os vícios. Enfim, enquanto os reis tradicionais exercem um poder, o rei cínico é o herói da resistência, ele combate consigo mesmo e pelos demais. Diante de uma vida soberana e tranquila, os cínicos propõem uma vida militante tanto de combate contra si e para si, quanto de luta contra os outros e para os outros. Por essas razões o cínico é considerado o anti-rei, o rei outro, pois ele esconde sua sabedoria no despojamento e na ascese voluntária. Rei desconhecido cujo reinado materializa o extravasamento da soberania tradicional. Reinado da derrisão. 
Podemos dizer que a vida canina ${ }^{15}$, o bíos kynikós, prolonga e ao mesmo tempo propicia uma reversão em relação à vida não dissimulada, à vida sem mistura, à vida reta e à vida soberana. A designação de Cão parece dar a entender em que sentido, no movimento cínico, viver na verdade significa levar às últimas conseqüências os desdobramentos da alétheia quando a efígie dos costumes é radicalmente alterada. 1) O bíos alethès, a vida na alétheia era uma vida não dissimulada, que nada ocultava e de nada se envergonhava. Elevada ao seu limite é a vida desavergonhada, despudorada e impudica do cão cínico quando ele realiza em público aquilo que as pessoas normalmente escondem (comer em praça pública ou se masturbar diante dos outros e demais atividades que evocam a animalidade da vida humana); 2) a vida sem mistura e independente, por sua vez, encontra seu prosseguimento, mas também seu limite, na vida que não necessita de nada e se contenta com o que se tem; 3) A vida reta, que obedece à lei (o nomos) encontra sua continuidade, mas também sua reversão na vida diacrítica, na vida latidora que distingue amigos $\mathrm{e}$ inimigos, os amos e os outros; 4) A vida soberana, tranquila e senhora de si tem sua continuidade, mas também seu limite na soberania entendida como vida de combate e de serviço, da não necessidade de ninguém que a proteja.

Se o cinismo introduz o tema da verdadeira-vida como vida outra, a alteridade da vida outra se encontra não na escolha de um estilo de vida honrado e soberano, mas na prática da combatividade cujo horizonte é a possibilidade de construir um mundo outro. Como verdadeira vida, vida outra e mundo outro, o cinismo se constitui na matriz de uma experiência ética fundamental no Ocidente.

\section{Considerações finais}

Não se trata nesse momento de propor uma conclusão. Nosso intuito é somente demonstrar que no pensamento tardio de Foucault encontramos escolhas teóricas e modos de problematização irredutíveis ao que normalmente se convencionou designar como "último Foucault". Ao tomar como recorte somente os cursos de 1983 e 1984, inicialmente pode-se apontar a insistência de fazer uma história outra em relação às "fontes" tradicionais da História da Filosofia. Essa História normalmente se limita a

\footnotetext{
150 termo "Cínico" provém da palavra grega kynikoi, que significa "semelhante ao cão". Pode ter sido uma referência ao local onde Antístenes, o primeiro cínico, escolheu seu domicílio, no ginásio de Cinosarges. (DIÓGENES LAÉRCIO, 1965, p. 13). A passagem a qual alude Foucault é esta: "Antístenes, tu viveste como um cão, mas tu mordias somente pelas palavras, e não com os dentes" (Tradução nossa) (Idem, 1965, p. 13).
} 
estudar e analisar textos canônicos dos grandes pensadores da Antiguidade: A República de Platão; A política de Aristóteles, As Enéadas de Plotino. Foucault também estuda estes grandes livros; entretanto, minimiza sua importância quase absoluta atribuída pela História da filosofia quando os compara a uma literatura "menor", praticamente insignificante, até os anos 1980. Em seguida, em vez de contrastar um e outro filósofo, Foucault prefere, por exemplo, colocar Platão contra si mesmo. Quando analisa o conceito de "alma" pelo fio condutor do cuidado de si em L'herméneutique du sujet, o Primeiro Alcibíades é privilegiado diante d'A República. Quando trata da parresía política e do ergon da filosofia, as Cartas V, VII e VIII são notoriamente mais importantes diante de textos muito conhecidos, como As leis. Foucault torna também estes diálogos menores os fundadores da prática filosófica no Ocidente. Assim é que em 1984 o Primeiro Alcibíades é apontado como a pedra fundamental da tradição metafísica no Ocidente; enquanto que o Laques - outro diálogo de juventude de Platão praticamente ignorado até então - é indicado como inaugurador da perspectiva da filosofia como estética da existência. A intenção é clara: não se trata simplesmente de rememorar uma filosofia esquecida, mas principalmente de realçar uma prática filosófica negligenciada no Ocidente. A possibilidade de outra História da filosofia tem a ver, ainda, com a escolha de correntes de pensamento tidas como "menores" na história da filosofia. Ainda hoje o cinismo não tem sido reconhecido como uma corrente de pensamento importante pelos manuais de História da Filosofia, mesmo em livros notáveis sobre a Antiguidade, como $O$ que é a filosofia antiga?, de Pierre Hadot. Não obstante, é inegável que o curso Le courage de la vérité reavivou os estudos em torno do cinismo e sua posição sobre a vida filosófica como verdadeira vida. ${ }^{16}$ A exaltação desses personagens filosóficos infames e de pouca glória, por seu estilo de vida singular e pelo escândalo estampado em seus corpos nus e suas vestes esfarrapadas é, na perspectiva de Foucault, a alteridade irredutível da filosofia.

Se o curso Le courage de la vérité pode ser designado como o testamento filosófico de Michel Foucault é porque nas análises derradeiras a respeito dos cínicos e sua herança socrática a articulação entre logos e bios

\footnotetext{
${ }^{16} \mathrm{Na}$ Situation du Cours, elaborada por Frédéric Gros ao Le Courage de la vérité, em sua nota 22, são apontados diversos estudos sobre os cínicos a partir do final dos anos oitenta, dentro e fora da França. Contemporaneamente ao curso são destacados os livros de P. Sloterdijk, Kritik der zynischen Vernunft, Francfort/M., Suhrkamp, 1983, traduzido ao francês como Critique de la raison cynique, trad. H. Hild1enbrang, Paris, Bourgois, 1987; e de A. Glucksmann, Cynisme et Passion, Paris, Grasset, 1981. (Cf. GROS, 2009, p. 322). No Brasil, destaco o recente livro de Ernani Chaves, Foucault e a verdade cínica. Campinas, SP: Phi, 2013.
} 
penetra na própria espessura da existência e é nessa imanência que a expressão viver na verdade aponta, também ela, para uma alteridade filosófica, no sentido que propusemos no artigo. Foucault foi buscar essa alteridade no cinismo para tomar distância tanto do logos normativo identificado ao discurso verdadeiro dos enunciados científicos, quase sempre indiferentes à vida; como também para se afastar do logos prescritivo que se sobrepõe à vida, ao modo de dogma religioso. Não se pode esquecer que essa alteridade é irredutível ao dizer-a-verdade problematizado no contexto da parresía política do curso Le gouvernemment de soi et des autres. A verdadeira vida cínica não está limitada ao uso da palavra pública arriscada no exercício de uma função específica, posto que a enunciação dos cínicos é o desdobramento de sua própria vida, onde quer que ela esteja. O discurso é provocativo e a pregação é crítica porque a vida, em si mesma, extravasa os limites do mesmo, dos consensos habituais e, nesse sentido, paradoxalmente, a verdadeira vida filosófica tem uma importância política.

A possibilidade de uma alteridade radical na imanência do mundo, observável no último curso de Michel Foucault, pode ser pensada também como a tentativa tardia de responder retrospectivamente a seus críticos que, desde o final dos anos 1978, identificavam seu pensamento a um reformismo moderado, simpatizante do neoliberalismo; ou ainda, viam no último Foucault, até meados dos anos 1990, o saudosista pensador da história da sexualidade e das técnicas de si entre os antigos. Impossibilitado teoricamente de dar conta da efetividade das resistências diante de sua concepção microfísica de poder, Foucault teria se subtraído às resistências políticas e se refugiado na ética da relação consigo. Entretanto, não é a primeira vez que Foucault trata dos cínicos e da perspectiva da alteridade. Em 1978, ele já havia esboçado a notoriedade desse movimento, quando apontou como tarefa crítica da filosofia a limitação do excesso do poder político e identificou no filósofo cínico o anti-déspota por excelência, à medida que ele se mantém independente em relação ao poder e zomba dele. Esse combate cínico, ao modo do escárnio e da autarquia, será amplamente desenvolvido no curso de 1984 (Cf. FOUCAULT, 1994, p. 537). Por certo, a combatividade, como vida militante, é um tema que acompanha o pensamento e a vida de Foucault desde sua juventude, que coincide com o período imediatamente após a Segunda Guerra mundial. O desgosto da juventude francesa diante de uma sociedade que havia permitido o nazismo e apoiado maciçamente De Gaulle não permaneceu alheio a Foucault. Diante disso, ele lembra: "A experiência da guerra nos havia demonstrado a necessidade da urgência de uma sociedade radicalmente diferente daquela na qual vivíamos. (...) Queríamos ser completamente outros em um mundo 
completamente outro" (FOUCAULT, 1994b, p. 49). Essa transformação de si mesmo indissociável da transformação imanente do mundo poderia ser evocada como o ponto de equilíbrio, também no último Foucault, entre o cuidado de si e a parresía cínica. Quando estudou os estóicos em L’herméneutique du sujet, foi acentuado o tema da conversão, da transformação de si mesmo; quando problematizou os cínicos, foi apontado como um de seus desdobramentos contemporâneos a combatividade radical, a vida militante comprometida com a transformação das relações políticas e sociais. A conversão a si, paradoxalmente, impõe a atitude de extravasamento dos limites a partir dos quais nos tornamos prisioneiros de nós mesmos e, nesse sentido, é descartado qualquer refúgio em uma ética solipsista. Quanto à combatividade proposta a partir da parresía cínica, sua casa é a praça pública, lugar de visibilidade total, da exteriorização escandalosa da efemeridade e arbitrariedade dos convencionalismos morais e políticos.

Nesse sentido, a perspectiva da alteridade no último Foucault assemelhase a um pêndulo a partir do qual, de um lado o cuidado de si deixa de se referir a uma interioridade a ser preservada ou descoberta; e, de outro, a parresía cínica, no sentido de vida combativa e militante, jamais pode ser situada como uma crítica situada totalmente fora do jogo da governamentalidade política. A alteridade a que conduz a verdadeira-vida envolve um incessante combate: contra o refúgio na tranquilidade da cidadela interior e contra o conformismo diante das artificialidades da polis e do modo como ela é governada. Sem remeter a um modo de vida totalmente outro como um além, separado da imanência do mundo, e sem conduzir essa imanência a uma interioridade a ser preservada, a alteridade que Foucault identifica nos cínicos não designa uma ontologização da vida, mas o excesso de sua visibilidade inquietante em relação a qualquer discurso que pretenda capturá-la em sua identidade e esgotá-la em sua verdade.

\section{Referências}

BODEI, R. "Dire la Verità". In: FOUCAULT, M. Discorso e verità nella Grecia Antica. Roma: Donzelli Editore, 1997, p. VII-XXII.

CHAVES, E. Foucault e a verdade cínica. Campinas, SP: Phi, 2013.

DIOGĖNE LAERCE. Vie, doctrines et sentences des philosophes illustres. Traduction, notice et notes par Robert Genaille. Tome II. Paris: GFFlammarion, 1965.

FOUCAULT, M. "La philosophie analytique de la politique". In : Dits et écrits, III. Paris: Gallimard, 1994a, p. 534-570. 
. "Entretien avec Michel Foucault". In: Dits et écrits, IV. Paris: Gallimard, 1994b, p. 41-95.

. Le Gouvernement des vivants. Cours au Collège de France. 19791980. Paris: EHESS/Gallimard/Seuil, 2012.

. L'Herméneutique du sujet. Cours au Collège de France, 1981-1982. Édition établie par François Ewald et Alessandro Fontana, par Frédéric Gros, Paris: Seuil/Gallimard, 2001 (Coll. Hautes études).

. Le gouvernement de soi et des autres. Cours au Collège de France, 1982-1983. Édition établie par François Ewald et Alessandro Fontana, par Frédéric Gros. Paris: Gallimard/Seuil: 2008. (Coll. Hautes études).

. Le courage de la vérité. Cours au Collège de France, 1983-1984. Édition établie par François Ewald et Alessandro Fontana, par Frédéric Gros. Paris: Gallimard/Seuil: 2009. (Coll. Hautes études).

. Histoire de la séxualité: l'usage des plaisirs. Paris: Gallimard, 1984.

. Discourse and Truth: The problematization of Parrhesia. Evanston, Ill: Northwestern University Press, 1985.

GABILONDO, A.; FUENTES MEGÍAS, F. "Introducción”. In: FOUCAULT, M. Discurso y verdad en la antigua Grecia. Barcelona: Paidós, 2004, p. 11-33. HADOT, P. O que é a filosofia antiga? São Paulo: Loyola, 1999.

JAFFRO, L. "Foucault et le stoïcisme. Sur l'historiographie de L'herméneutique du sujet”. In: GROS, F.; LÉVY, C. Foucault et la philosophie antique. Paris: Kimé, 2003, p. 51-84.

LORENZINI, D.; REVEL, A.; SFORZINI, A. (Orgs.). Michel Foucault: éthique et vérité 1980-1984. Paris: Vrin, 2013.

PLATON. Apologie de Socrate. Criton. 2. ed. corrigée. Introductions et traductions inédites de Luc Brisson. Paris: CF-Flammarion, 1997.

. Lettres. 3. ed. Corrigée. Traducción inédite et présentation par Luc Brisson. Paris: GF- Flammarion, 1997, p. 133-250.

REVISTA DE FILOSOFIA AURORA. Pontifícia Universidade Católica do Paraná, Curitiba, v. 23, n. 32, jan./jun. 2011. 